\title{
JÁTÉKOS KREATIVITÁS FEJLESZTÉS TAPASZTALATAI EGY SZLOVÁKIAI ÓVODÁBAN
}

\section{Szerzők:}

Nagy Lehocky Zsuzsa

Konstantin Filozófus Egyetem Nyitra

(Szlovákia)

Juhos Flóra

(Szlovákia)

Első szerző e-mail címe:

znlehocka@ukf.sk

\section{Lektorok:}

Patai Ilona (PhD)

Konstantin Filozófus Egyetem Nyitra

(Szlovákia)

Hrbácsek Noszek Magdaléna

Konstantin Filozófus Egyetem Nyitra

(Szlovákia)

és további két anonim lektor...

\begin{abstract}
Absztrakt
E tanulmány célja, hogy bemutassuk, hogyan lehet az OxIPO modell alapján kreativást fejlesztő játékokat megvalósítani már az óvodai nevelés keretein belül. Röviden meghatározzuk a kreativitás fogalmát, majd ismertetjük, hogy mennyire fontos az, hogy maga a pedagógus kreatívan álljon az óvodai foglalkozások tervezéséhez. Ismertetjük a kreatív pedagógus jellemzőit és személyiségjegyeit. Bemutatjuk az óvodáskorú gyerekek kreativitást támogató játékok megvalósításának tapasztalatait.
\end{abstract}

Kulcsszavak: kreativitás, pedagógus személyisége, játékok

Diszciplina: pszichológia

\section{Abstract \\ EXPERIENCES OF THE PLAYFUL DEVELOPMENT \\ OF THE CREATIVITY IN A SLOV AK KINDERGARTEN}

The aim of this study is to show how it is possible to put creativity developing games into action within the framework of preschool education based on the OxIPO model. Briefly we analyze the meaning of creativity, then describe how important it is for the teachers themselves to be creative during plannings. The characteristics and personality 
traits of a creative teacher are described. We present the experiences of implementing games that support the creativity in preschool children.

Keywords: creativity, personality of teacher, games

Disciplines: psychology

Nagy Lehocky Zsuzsa és Juhos Flóra (2021): Játékos kreativitás fejlesztés tapasztalatai egy szlovákiai óvodában. OxIPO - interdiszciplináris tudományos folyóirat, 2021/4, 51-62. doi: 10.35405/OXIPO.2021.4.51

Ahhoz, hogy megfelelően tudjuk fejleszteni a gyermekeket, elengedhetetlen, hogy a pedagógus személyisége és hozzáállása is pozitív viszonyban legyen a kreativitással. Csak így mehet végbe hatékony fejlesztés. A gyermekek egy alapvető jellemzője, hogy eredendően kreatív személyek. Az OxIPO modellen (bővebben lásd Mező és Mező, 2019) alapuló képességfejlesztést terveztünk, melynek során, olyan játékokat játszunk a gyermekekkel, amelyek célirányosan az alkotókészség megjelenését helyezték előtérbe. $\mathrm{Az}$ organizációt a játékok szervezése és előkészítése jelentette, a játékok instrukciói minden esetben az inputként értelmezhetők, a process pedig a külső ingerek kognitív, emocionális és gyakorlati feldolgozása. Az eredmények, vagyis ezen modell alapján az output, jelen esetben a gyerekek rajzai, megoldásai voltak. Megfigyeltük, hogy a gyermekek mennyire ötletesek, milyen a problémamegoldó készségük, mennyire alkalmazzák fantáziájukat, hogyan reagálnak új számukra ismeretlen helyzetekre.

\section{A kreativitás meghatározása}

A kreativitás egyértelmú meghatározása máig vitatott, mert egy olyan összetett képességről van szó, amely új és hasznos dolgok, ötletek előállítására késztet a múvészetek, a tudományok, a technika, az irányítás, szervezés terén, vagy akár a hétköznapok bármely területén (Mező, és Mező, 2011).

A ,kreativitás” kifejezés egyáltalán nem újkeletű, főleg ha a szó eredetét nézzük, ami a latin „creare” szóból ered, ami „,alkotni, előállítani” jelentéssel bír. A kreativitás kifejezéshez kapcsolódik még az inspiráció, az intuíció is. Az újabb „kreativitás” kifejezés az angol „creativity” szóból származik, amelyet J. P. Guilford vezetett be, amikor az Amerikai Pszichológiai Társaság leendő elnökeként a kreativitás témájában tartott beszédet. Azóta a kutatási tevékenység robbanásszerű növekedéséről beszélhetünk a kreativitás területén.

A 21. század alapvető fogalmai közé tartozik a kreativitás, kreatív ember, kreatív ötletek. Az élet minden területén haszná- 
latos fogalmakról, szófordulatokról beszélünk, legyen szó magánéletről, munkahelyről vagy akár a gyermekekről. Napjainkban egyre nagyobb hangsúlyt fektetnek a kreativitásra, az ötletességre, a teljesítményre.

Az alkotóképesség meghatározására sokféle értelmezés született mind a laikusok, mind pedig a szakemberek között. A kreativitás egyértelmű meghatározása máig vitatott, mert egy olyan összetett konstruktumról van szó, amely új és hasznos dolgok, ötletek előállítására késztet a múvészetek, a tudományok, a technika, az irányítás, szervezés terén, vagy akár a hétköznapok bármely területén.

Csikszentmihályi szerint a kreativitás nem csupán egy személy tulajdonsága, hanem úgyis kell értelmezni, mint egy társadalmi tulajdonságot, mint egy kultúra tulajdonságát, illetve, mint bizonyos történelmi korszak tulajdonságát (lásd például: Csikszentmihalyi, 1988).

Vigotskij szerint az alkotás nemcsak ott van jelen, ahol az ember nagy történelmi jelentőségű műveket teremt, hanem mindenütt, ahol az ember elképzel, kombinál, változtat, valami újat teremt, bármilyen szegényesnek is tûnjék az a zsenik alkotásához képest (Vigotszkij, 1967).

$\mathrm{Az}$ alkotóképesség tehát új, értékes és egyedi ötletek, megoldások, gondolatok létrehozása. A kreativitás egy folyamat. Egy olyan folyamat, amely az emberben zajlik, a külső ingerek és belső impulzusok kölcsönhatása alapján. Ennek az interakciónak az eredménye pedig egy olyan termék, amely újdonsággal és értékkel jellemezhető. A lényege az elemzés, szintézis, strukturálás és kombináció rendkívül rugalmas folyamata egy új megoldás felé orientálva, ami egy szokatlan és meglepő termékben tükröződik, és amely mások számára is hasznossá és értelmessé válik.

\section{$\mathrm{Az}$ óvodapedagógus személyisége}

A pedagógus személyisége meghatározó tényező az edukációs folyamatban. Fontos lenne, hogy olyan szakképzett, rátermett pedagógusokat alkalmazzanak az intézmények, akik képesek elősegíteni a gyermekek sokoldalú, pozitív irányú értelmi és érzelmi fejlődését. Ahhoz, hogy kreatív, jó problémamegoldó képességekkel rendelkező, kötetlen gondolkodású gyermekeket tudjunk nevelni, hasonló képességekkel rendelkező pedagógusokra van szükség. A továbbiakban összefoglaltuk, hogy milyen a megfelelő pedagógiai hozzáállás az alkotóképesség fejlesztéséhez.

Ha összevetnénk a pedagógusok felé irányuló elvárásokat és egy modellt alkotnánk belőle a követelmény a következő lehetne:

\section{Kognitivv elvárások:}

Intelligencia. Információk felfogásának, megértésének a képessége, az új adatok, információk tudásként való elraktározását jelenti.

Kommunikációs képességek. Elsősorban jó beszédkészséget jelent, de ide tartozik az aktív hallgatás, az egymásra való oda- 
figyelés képessége egyaránt. Szóban és 1rásban is megnyilvánuló képességek.

Konstruktív és didaktikai képességek. Olyan pedagógiai szituációkat legyen képes létrehozni, amely során a gyermekek észrevétlenül játszva képesek elsajátítani az új ismereteket

Szervezőképesség.Jó időgazdálkodási érzék, a feladatok, prioritások megállapítása, levezetése tartozik ide. Fontos, hogy a pedagógus jó vezető legyen.

Érzelmi - motivációs elvárások:

Érzelmi intelligencia. Tisztában kell lennie saját érzéseivel, képesnek kell lennie felismerni mások érzelmeit. Fontos, hogy az empátiát alkalmazza tanítása során.

Társas intelligencia. Aki a társas intelligencia különleges képességével rendelkezik, olvasni tud a másik ember gondolataiban, belelát a lelkébe, szivébe, együtt érez vele. Megismeri az adás örömét, és ezzel örömet szerezhet másoknak is (v.ö.: Goleman, 2012).

Önreflexió, önirányítás képessége. Képes legyen értékelni önmagát, reálisan lássa hibáit, tévedéseit. Ugyanakkor képes legyen ezeken javítani. Önuralom képessége is ide sorolható.

Játszani tudás. Képes legyen „lehajolni” a gyermekhez. A játék élményét át tudja élni a gyermekkel.

Kreativitás. Kreatív eszközöket, módszereket alkalmazzon tanítása során.

Vezetői képességek. Irányítás, döntéshozatal, határozott fellépés bizonyos helyzetekben.
Objektivitás. Fontos, hogy a gyermekek körében tiszteletet tudjon kialakítani, éreztesse, hogy ő a vezető, enélkül ugyanis nem lenne képes irányítani a csoportot. Ugyanakkor olyan vezető legyen, aki figyelembe veszi a gyermekek véleményét, akaratát döntéshelyzetekben. Megbeszéli a gyermekekkel az adódó problémahelyzeteket, közös megoldásra törekszik. Minden helyzetben tudjon objektív maradni, fontos döntésekben tárgyilagos, pártatlan, elfogulatlan tudjon maradni.

Flow - alkalmasság. A flow-élmény az elménknek egy olyan állapota, amely során teljesen beleéli magát abba, amit épp csinál. Örömöt okoz az egyén számára ez az élmény, így képes benne teljesen feloldódni (Csikszentmihalyi, 1988, Hercz, Ráczné Oláh és Takács, 2015, Mérô László, 2010).

Miron Zelina évtizedek óta foglalkozik a tanárok kreativitásával. Több múvében is taglalja, hogy milyennek kellene lennie egy kreatív pedagógusnak, annak érdekében, hogy a gyermekek kreativitását is fejleszteni tudja. A következő ajánlásokat fogalmazta meg:

1) A pedagógusnak erőfeszítéseket kell tennie új módszerek, megközelítések használatával az oktatási folyamatban. Fontos, hogy ezekkel kísérletezzen, hogy minél változatosabb megismerési folyamatokat biztosítson a gyermekek számára.

2) A hatékonyság vizsgálata is elengedhetetlen. Ha az oktatási folyamatban valami nem úgy múködik, ahogy kellene, akkor fontos a változtatás képessége. 
3) Kreatívan keresni, megtanítani és kiegészíteni a gyermekek számára az új vagy már ismert információkat.

4) Stratégiai szempontból keresse a kreatív módszereket a tanításban különösen a tanulók mentális funkcióinak a fejlesztésében.

5) A tanításban alkalmazzon eltérő gondolkodást a kreativitás szellemében. Tartsa szem előtt az eredetiség, rugalmasság és a folyékonyság kialakításának, fejlesztésének feladatát.

6) Használja és gyakorolja a heurisztikus tanítást, az integrációt és az alternatív megközelítéseket.

7) Az emberek pszichés tulajdonságainak figyelembevétele, a pihenés, az empátia beépítése az oktatásba, az oktatási folyamatok korszerüsítése az igények alapján.

8) Humanista elvek szellemében nevelni és oktatni hangsúlyt helyezve a tanúlókkal, az önmagával, az iskolával és a tanítás tartalmával fennálló kapcsolatok megtapasztalására (Zelina, 1997).

Ha a gyermekek olyan közegbe kerülnek, ahol a pedagógus az alkotóképességre pozitívan ható légkört képes kialakítani, sokkal hatékonyabban képesek megélni, fejleszteni kreatív képességeiket.

A következőkben összegyűjtöttünk pár olyan tulajdonságot, amelyek által a pedagógus elősegítheti a gyermekek megfelelő, játékos fejlesztését az alkotóképességük szempontjából:

- Gyermekek szabadon gondolkodhatnak.
- Eredetiségre ösztönöz.

- Kreatív módszerekkel, stratégiákkal dolgozik.

- Optimizmus jellemzi, a gyermekek érzik, hogy ha valami nem sikerült az is csak egy tanulság a további fejlődésre.

- Fontosnak tartja az együttmúködést, egymás segítését és alkalmazza a csapatmunkát.

- A tanár a gyermekekkel együtt értékel, mindenki véleménye fontos.

- Mindenkinek biztosítja a szabad érvényesülés jogát.

- Támogatja az önértékelést.

- Esélyt ad a tapasztalatokon keresztül végbemenő tanulásra.

- A gyermekeket megoldandó problémahelyzetek elé állítja, ezzel is elősegítve az élményszerű tanulást.

- Megtanít a tanulásra.

- Mint tanácsadó, illetve szervező pozícióban lép fel.

- Nyitott kommunikációt részesíti előnyben (Nagy, 2017).

Ha ezen tulajdonságok többségével rendelkezik egy pedagógus, szinte biztosak lehetünk benne, hogy a gyermekek megfelelően tudnak fejlődni saját kreativitásukban. Ezekkel a jellemvonásokkal ugyanis ösztönzik a gyermekeket és példaképpé válik számukra. A gyermekek akkor tudnak hatékonyan fejlődni, kibontakoztatni, fejlődni, megélni kreativitásukat, ha a pedagógus támogatja őket és maga is a kreativitás szellemében próbálja a legjobbat nyújtani a gyermekeknek. 


\section{Kreativitást támogató játékok az óvodában}

A következőkben bemutatjuk azon játékokat, melyek a szlovákiai nyárasdi óvodában valósultak meg. Mielőtt sor került volna a foglalkozásokra többször is meglátogattuk a gyerekeket, hogy megismerjük őket. Megfigyeléseink alapján több forrásból válogattuk össze a játékokat a korcsoport fejlettségi szintjének megfelelően. A játékokat egy hónapon keresztül valósítottuk meg a gyerekekkel.

Óvoda: Magyar tannyelvű óvoda Nyárasd

Korcsoport: 3-4 éves gyerekek, az óvoda kis-középső Mackó csoportja

Csoportvezető óvónő: Nagy Renáta

Csoportlétszám: 19 gyermek

Nemi eloszlás a csoportban: 7 fiú, 12 lány

\section{A játékok célja}

Elsődleges célunk a játékokkal az volt, hogy az OxIPO modell alapján foglalkozásokat valósítsunk meg az óvodában és mindezzel támogassuk a gyermekek alkotóképességének fejlődését. Igyekeztünk minél változatosabb, izgalmasabb játékok segítségével elérni ezt. A játékok értékelésénél figyelembe vettük Guilford szempontjait is, amik alapján megállapította, hogy milyen is egy produktív gyermek. Megfigyeltük, hogy a feladatok megoldásánál megjelennek-e a következő képességek:

- Könnyedség (Fluencia)

- Rugalmasság (Flexibilitás)
- Kidolgozottság (Elaboráció)

- Eredetiség (Originalitás)

- Érzékenység (Szenzibilitás)

- A problémák újra fogalmazásának a képessége (Redefinálás)

\section{Játékok}

1. játék: Rajzoljunk valamit! (Kazal, 2017)

Létszám: 14 gyermek (8 lány, 6 fiú)

Eszközök: színes ceruza, papír

Input (a játék ismertetése): A lapon kör alapú ábrát láttak a gyerekek, tehát az ábra, amit ki kellett egészíteniük egy egyszerű kör volt. Elmondtuk a gyermeknek, hogy bármit lerajzolhatnak, ami arról a körről eszükbe jut. Az ábrákat úgy kell nagyobb rajzokká kiegészíteni, hogy minden rajz más és más figurát, vagy eseményt ábrázoljon.

A gyerekek igénylik a pontos instrukciókat. Nehéz volt, úgy pontos instrukciót adni, hogy közben ne mondjuk meg nekik pontosan, hogy mit rajzoljanak. Ha példát mondtunk volna, hogy például a körből lehet labdát rajzolni, akkor mindenki labdát rajzolt volna. Ezért annyit hangsúlyoztunk csak ki, hogy a kör legyen a rajzunk része, olyan valamit rajzoljanak, ami kör alakú, vagy nagy mértékben jelen van benne a kör.

Tanári utasítás: „Nézd meg a lapon látható kört és alkoss belőle egy rajzot! Rajzold le ami eszedbe jut!"

Process: Segítség nélkül, szinte rögtön tudták mit szeretnének kihozni a mintából. Mindenki önállóan találta ki, hogy mit fog rajzolni. A gyerekek hozzáállása a fela- 
dathoz pozitív és érdeklődő volt. Nagyon szívesen rajzolták tovább az ábrákat, senki nem vonta ki magát a feladat alól. A végeredményre büszkék voltak és kérték, hogy vihessék haza megmutatni szüleiknek.

Output: A gyerekek ötletei teljes mértékben érvényesültek, az alapinstrukciókon kívül nem kaptak más utasítást. Több, Guilford alapján meghatározott jellemző is megjelent a gyermekek rajzolása során, ezek a következők: könnyedség (fluencia), rugalmasság (flexibilitás), Kidolgozottság (elaboráció), eredetiség (Originalitás), Problémák újra fogalmazásának a képessége (redefiniálás). Nagyon szép mások által is felismerhető rajzok születtek (lásd: 1. kép).

\section{Játék: Rajzoljunk zenére! (saját ötlet)}

Létszám: 13 gyermek (8 lány, 5 fiú)

Eszközök: Színes ceruzák, üres A4-es papírlap

Input, a játék ismertetése: Komolyzene lejátszása közben kell lerajzolniuk a gyermekeknek, hogy mi jut eszükbe a zenéről. Mi Vivaldi „Négy évszak” című mûvét hallgattuk a gyerekekkel. Ezen belül is a
„Tavasz” szimfóniáját alkalmaztuk. A rajzolásra körülbelül 10 perc elegendő volt.

A zene mindig nagyon ösztönző hatással van a gyerekekre. Amint megszólal valamilyen dal, a gyerekek érdeklődve fordulnak felé. Halkan engedtük a zenét, amíg elmondtuk, hogy most mit fogunk játszani.

Tanári utasítás: „Hallgassd meg a zenét! Alkoss a zene alapján egy képet! Rajzold le, ami a zenéről eszedbe jut!"

Process: A gyerekek figyelmét, mind a rajzolás, mind a zene nagyon jól lekötötte. A gyermekek nem kaptak segítséget a feladat megoldásához. Azon kívül, hogy elmondtuk nekik, hogy bármit rajzolhatnak, ami az eszükbe jut teljesen magukra voltak utalva. Szinte egytől egyig minden gyermeknek a tavasszal kapcsolatos dolog jutott eszébe. Volt, aki magát a tavaszt, volt, aki virágot, napot, vizet vagy valamimilyen gyümölcsöt rajzolt, mert ez jutott eszébe a zenérôl. Ez azért az egyértelműen helyes problémamegoldás, mert Vivaldi „Tavasz” szimfóniáját hallgatták. Tehát kiderült, hogy 3-4 éves gyermekek is képesek ezt felismerni.

\section{1. kép: Rajzoljunk valamit! - Emberke sapkával, Ugráló, Napocska - forrás: saját fénykép}

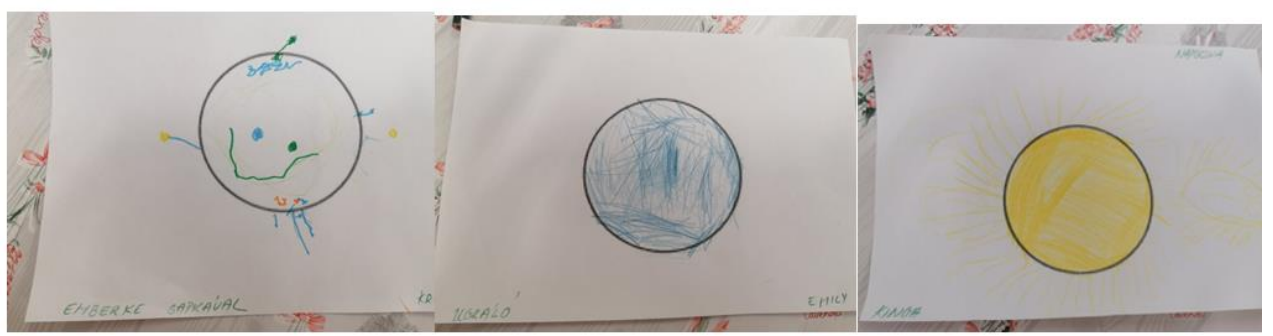




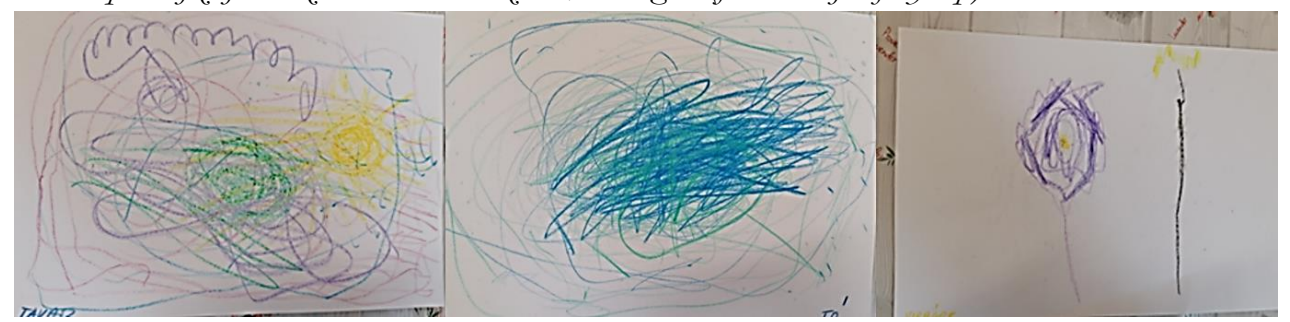

Output: A gyermekek nagyon jól reagálnak a zenére és minden zenével kapcsolatos tevékenységre. A gyermekek ötletei, kreativitása teljes mértékben kibontakozhatott a feladat végzése közben. A feladatban a könnyedség (fluencia), eredetiség (originalitás), érzékenység (szenzibilitás) jelent meg.

Amikor a gyerekek készek voltak mindenki bemutathatta a rajzát és elmondhatta, hogy mit rajzolt. Szépen figyeltek egymásra és mindenki várta, hogy szerepelhessen. A gyerekek együttműködően viselkedtek, figyelmesek, aktívak voltak. Tetszett nekik a feladat, örültek mikor a műveik kikerültek a faliújságra (lásd: 2 . kép).

\section{3. játék: Leonardo da Vinci festményei}

(Clegg és Birch, 2005)

Létszám: 15 gyermek (8 lány 7 fiú)

Eszközök: Rajzlap, színesceruza

Input: a játék ismertetése: Egy gyermek kap egy rajzlapot. A szemét bekötjük és rajzolnia kell a papírra bármit, ami éppen eszébe jut. Amint úgy gondolja, hogy kész a gyermek kéri, hogy vegyük le a kendőt. Végül szembesül rajzával és megállapítja, hogy sikerült-e az elképzelést a rajzlapra vetíteni.

Tanári instrukció: „Figyelj a kezedre és alkoss egy képet! Rajzold le amit szeretnél!"

Process: Furulya segítségével keltettük fel a gyermekek figyelmét. Mikor mindenki körülöttünk volt, elmondtuk nekik, hogy most két csoportra fogunk osztódni. 5 gyermek jön velem az asztalhoz a többiek pedig maradnak körjátékozni a másik óvónénivel. Amikor az első 5 gyermek végzett jöhetett a következő 5 és így tovább. Nagyon érdekelte őket, hogy mi fog asztalnál történni, mindenki szeretett volna minél hamarabb sorra kerülni. Mikor az asztalhoz mentünk elmondtuk a gyermekeknek, hogy most be fogjuk kötni a szemüket és úgy fognak rajzolni.

Output: A gyermekek számára nem okozott nehézséget a feladat megoldása. Sokan kérték, hogy a kezüket irányítsuk a papír közepére és segítsünk nekik színeket választani. Ebben segítségükre is voltunk. Minden gyermek ötlete, kreativitása kibontakozhatott. Az ötlet kitalálásában és a rajz konkrét elkészülésében magukra voltak utalva. A rajz elkezdése előtt kér- 
deztük meg tőlük, hogy mit szeretnének majd a papíron látni miután levettük a kendőt, a rajz elkészülése után pedig együtt értékeltük, hogy sikerült-e úgy lerajzolni, ahogy elképzelték. Guilford jellemzői közül a következőket észleltük a játék során: könnyedség (fluencia), rugalmasság (flexibilitás), érzékenység (szenzibilitás).

A gyerekek nagyon lelkesen indultak neki a feladatnak. Új volt számukra, hogy a látás érzékszerve nélkül rajzolhattak. Mindenki elégedett volt a saját alkotásával (3. kép).

\section{4. játék: Ki vagyok én?}

(B. Clegg és P. Birch, 2005)

Ezt a játékot menet közben módosítottuk, mivel az eredeti játék a gyerekeknek nehéznek bizonyult.

Input: Először az óvónő kezdi a játékot. Eljátszik egy mesehőst, hangjával, mozdulataival, beszédével, tevékenységével imitálja a szerepet. Végül a gyerekek kitalálják, hogy kit játszott el. Utána követ- keznek a gyerekek. Először a gyermek megsúgja az óvónőnek, hogy milyen szerepbe bújik, majd eljátssza azt. A többiek célja, hogy kitalálják.

Tanári utasítás: „Csendben mutogasd el kiválasztott társad, úgy, hogy a többiek kitalálják kire gondoltál!’

Process: Nem mesehősöket kellett imitálni és kitalálni, hanem valakit a csoportból kellett kiválasztani és ôt úgy elmutogatni, hogy valaki ráismerjen, hogy ki is lehet az. A gyermekek fellelkesültek és egymást nagyon szépen el tudták játszani. A gyermekek könnyen ki is tudták találni, hogy épp kiről lehet szó a csoportból. Olyan is előfordult, hogy a gyermek magára ismert és közölte, hogy épp őt játssza el a társa. Képesek voltak gyorsan reagálni és felismerni a megoldást. Dinamikus játék keletkezett a végére. Ha valaki nem a megfelelő személyre tippelt az eljátszó azonnal mondta, hogy nem helyes a válasz. Indulhatott tovább a találgatás. Amikor valaki kitalálta a helyes megoldást a gyermek szólt, hogy helyes a válasz.

\section{3. kép: Leonardo Da Vinci festményei - Fü, Alma, (forrás: saját fénykép)}

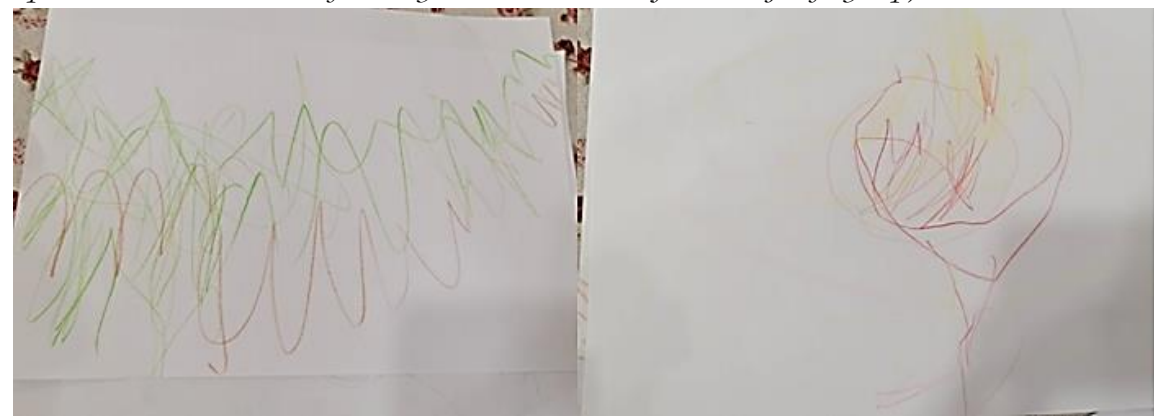


Output: Guilford megállapításaiból kiindulva a következő jellemzőket tudtuk megfigyelni a feladatban: rugalmasság (flexibilitás), eredetiség (originalitás).

A gyermekek élvezték a játékot. Minél tovább játszottuk, annál ügyesebben és gyorsabban képesek voltak rájönni a megoldásra. A játék befejezése után kérték, hogy máskor is játsszuk ezt a játékot.

Vannak bizonyos játékok, amelyek alkalmassá tehetők minden korcsoport számára. Ez is egy ilyen játék. Egy apró elemet kellett változtatni a játék menetében és máris képes volt egy 3 éves gyermek is abszolválni a feladatot.

\section{5. játék: V arázslatos tárgyak}

Segédeszközök: Lezárható papírdoboz, kalap, furulya, papucs, karkötő, festőecset, csillámgömb.

Input: Van egy varászbőröndünk. Ebbe a varázsbőröndbe mindenféle ,varázslatos” tárgyat gyüjtünk. A gyermekek találják ki, hogy mi annak a tárgynak a varázs képessége. Majd miután kitalálták, hogy melyik tárgy milyen varázserővel bír, elmondjuk a tárgy életének egy meghatározó pillanatát.

Tanári instrukció: „Nézd meg jól a tárgyat és találd ki mi lehet a varázserője!”

Process: Furulya szóval hívtuk magunk köré a gyermekeket. Mikor már mindenki ránk figyelt, elmeséltük, hogy találtunk egy varázsdobozt, amiben sok-sok varázstárgy található. Egy a bökkenő, nekünk kell kitalálni, hogy mi a varázserője az adott tárgynak. Mikor ez megvolt, rákérdeztünk, hogy vajon mi lehetett a legjobb dolog, ami ezzel a tárgyal történt. Engedtük, hogy felpróbálják a kalapot, papucsot, elképzeljék, ahogyan csillaggá változnak vagy repülnek.

Output: A gyermekek nagyon aktívan gondolkodtak, hogy vajon mi lehet a tárgy szuperképessége, így végül nagyon kreatív válaszok születtek. Ötletbörzéhez hasonlóan zajlott a játék, ha valaki nagyon jót mondott a gyerekek maguk kérték, hogy válasszuk azt varázserőnek. A történet kitalálása nehezebb feladat volt számukra, itt szükség volt rávezető kérdéseket feltennünk, a megoldás megszületése érdekében.

A gyerekek ötletei érvényesültek. Mindenkinek engedtük az ötletei kibontakoztatását. Mindenkit meghallgattunk, majd együtt döntöttünk, hogy melyik ötlet az, ami a legtöbb résztvevőnek tetszik. Megjelent a játék során a rugalmasság (flexibilitás), eredetiség (originalitás), és a problémák újra fogalmazásának (a redefiniálás) képessége is. A következő meghatározásokra jutottunk:

- Kalap. Varázserô: csillaggá képes változtatni viselőjét. Csillagként szörnyeket győzhetünk le vele. Történet: egy sárkánnyal harcolt a királyfi, felvette a kalapot csillaggá változott és sikerült legyőzni a sárkányt.

- Furulya. Varázserő: ha valaki belefúj, ott terem egy varázspóni és elviszi őt bárhová ahová csak szeretné. Történet: egy kislány elveszett és nem találta 
a szüleit, de nála volt a varázsfurulya, belefújt és a póni haza vitte őt.

- Papucs. Varázserő: aki viseli tud repülni. Történet: A papucs segített elmenekülni a királylánynak a gonosz boszorkány elől.

- Karkötő. Varázserő: ha valaki felveszi azonnal gyönyörű ruha terem rajta. Történet: egy kislány elment az anyukájával fényképeszkedni. Az anyukája elfelejtette a kislány szép ruháját elvinni. Ekkor felvette a karkötőt és gyönyörű hercegnős ruha termett rajta.

- Festőecset. Varázserő: amit festünk vele életre kel. Történet: egy szegény családnak nem volt háza, de ráakadtak a varázslatos festőecsetre. Rajzoltak maguknak házat és boldogan éltek.

- Csillámgömb. Varázserő: Fel képes gyorsítani az időt, ha megrázzuk. Történet: egy kisfiú az oviban sírt, mert szerette volna, hogy jöjjön érte az anyukája. A gömbbel felgyorsította az időt és már mehetett is haza a szüleivel.

A játékok megvalósítása után a gyermekek kérik ezeket a játékokat, azóta is gyakran beépítik ezekt szabad játékukba. $\mathrm{Az}$ óvodapedagógus elmondása alapján a többi nevelési terület foglalkozásain belül is látható, hogy a gyermekek alkotóképessége fejlettebb, mióta nagyobb hangsúlyt fektetnek az ilyen típusú játékok alkalmazására. Fontos, hogy az óvodapedagógusok ne hanyagolják el a kreativitás fejlesztésére alkalmas feladatok hasz- nálatát. A gyermek kreativitását egész élete során kamatoztatni fogja. Ahhoz, hogy felnőtt életében is képes legyen könnyedén venni az akadályokat és problémáit hatékonyan tudja megoldani mindenképp szükséges, hogy már óvodában elkezdjük fejleszteni az erre vonatkozó képességeket.

Akkor tudunk igazán hatékonyak lenni, ha minden gyermeket külön személyiségként kezelünk, értékeljük képességeiket, engedjük őket kibontakozni, mindezek mellett pedig megpróbáljuk belőlük kihozni a maximumot, hiszen mindenki másban és másképpen jó.

\section{Zárógondolatok}

Az OxIPO-modell (Mező és Mező, 2019) hatékonyan alkalmazható az óvodai nevelésen belül akkor is, amikor a kreativitás fejlesztést célozzuk meg. A kreatív pedagógus ösztönző a gyermekek szemében, segít, hogy produktív, fantáziadús felnőtt váljék tanítványaiból. Minden gyermekben, ott gyökerezik az alkotóképesség. Megfelelő szervezéssel az információfeldolgozási komponensek már kisgyermekkorban értékes eredményeket mutatnak. Engedjük kibontakozni a gyermekeket, hiszen a gyermekek kreativitása egy olyan kincs, amelyet nem szabad hagyni elvesztegetni. Az alkotóképesség kibontakoztatásával olyan ablakokat nyithatunk a gyermekek felé, amin keresztül nemcsak sikeresen teljesíthetik kitűzött céljaikat az életben, hanem mindezt a 
tanulás pozitív élményeként, eredményeként élhetik meg.

\section{Irodalom}

Clegg, B. és Birch, P. (2005). Kreativita. Brno: CP Books, a.s., ISBN 80-2510549-0., p. 110.

Fodor, L. (2007). A kreativitás fogalma. Letöltés: 2020.01.17. Web: http://www.oracler.ro/fodlink/a $\% 20$ kreativ $\% 20$ szemely.html)

Goleman, D. (2012). Társas intelligencia. Budapest: Libri Kiadó, ISBN 978-963972-514-0, p.508.

Hercz, M., Ráczné Oláh, E. és Takács, N. (2015). Pályakezdố óvodapedagógusok túlélőkészlete. Szeged: Szegedi Tudományegyetem, ISBN 978-963-306-424-5.

Kazal, K. (2017). A kreativitás fejlesztése. Letöltés: 2019.10.20. Web: http://www.varazsbetu.hu/beszelgess unk/kreativitasfejlesztese/index.php?f bclid=IwAR25R2D6P8iliF-
Oykd41Rh0wDM sFrLNaLcAELY7w uRodo4t35eqm-IfGA)

Nagy, N. (2017). Ilyen egy jó pedagógus pszichológusokat és pedagógust kérdeztünk. Letöltés: 2020.01.21. Web: https://mindsetpszichologia.hu/2017 $\angle 11 / 23$ /ilyen-egy-jo-pedagoguspszichologusokat-es-pedagogustkerdeztunk/)

Mező Ferenc és Mező Katalin (2011): Kreativ és iskolába jár! K+F Stúdió Kft., Debrecen. ISBN 978-963-08-2435-4

Mező, F. és Mező, K. (2019). Az OxIPOmodell - az interdiszciplináris kutatások egy lehetséges értelmezési kerete. OxIPO- interdiszciplináris tudományos folyóirat, 2019/1, 9-21. doi: 10.35405/ OXIPO.2019.1.9

Zelina, M. és Zelinová, M. (1997). Tvorivý ucitel. Bratislava: Metodické centrum mesta Bratislavy, ISBN 80-7164-1928, p. 77 